\title{
Strategi Alternatif Pembelajaran Daring Mahasiswa Pendidikan Agama Islam Pada Masa Pandemi Covid-19
}

\author{
Unik Hanifah Salsabila, Irwan Ghazali, Zulnadi, Nisrina Khoirunnisa, Husnun Hanifah \\ 1Pendidikan Agama Islam, Fakultas Agama Islam, Universitas Ahmad Dahlan \\ Alamat e-mail unik.salsabila@pai.uad.ac.id \\ 2Pendidikan Agama Islam, Fakultas Agama Islam, Universitas Ahmad Dahlan \\ Alamat e-mail irwan1800031154@webmail.uad.ac.id \\ ${ }^{3}$ Pendidikan Agama Islam, Fakultas Agama Islam, Universitas Ahmad Dahlan \\ Alamat e-mail zulnadi1800031231@webmail.uad.ac.id \\ ${ }^{4}$ Pendidikan Agama Islam, Fakultas Agama Islam, Universitas Ahmad Dahlan \\ Alamat e-mail nisrina1800031244@webmail.uad.ac.id \\ ${ }^{5}$ Pendidikan Agama Islam, Fakultas Agama Islam, Universitas Ahmad Dahlan \\ Alamat e-mail husnun1800031120@webmail.uad.ac.id
}

\begin{abstract}
Abstrak
Pandemi covid-19 tengah melanda negara-negara diseluruh dunia termasuk Indonesia. Berbagai masalah yang disebabkan oleh pandemi muncul termasuk dalam bidang pendidikan yang mengakibatkan seluruh kegiatan belajar mengajar dilakukan secara daring untuk meminimalisir terjadinya penyebaran virus. Dalam pembelajaran Agama Islam terdapat beberapa tantangan saat mengajarkan kepada peserta didik terkait materi baik itu secara pemahaman konsep maupun praktik. Peserta didik, pendidik maupun praktisi pendidikan diharuskan untuk melek gawai sehingga diharapkan dapat mengikuti dan mendapatkan pembelajaran dari gawai sesuai anjuran kemendikbud yang mengharuskan semua melakukan Pembelajaran Jarak Jauh. Pendidik diharapkan mampu menyediakan banyak pilihan pembelajaran yang sesuai dengan kebutuhan setiap peserta didik sebagaimana disampaikan mendikbud bahwa harus mempersiapkan pembelajaran dalam bentuk blended learning. Penelitian ini bertujuan untuk memberikan gambaran pelaksanaan pembelajaran Pendidikan Agama Islam dengan strategi alternatif dan inovasi guna mempermudah jalannya pembelajaran. Penelitian ini menggunakan pendekatan kualitatif dilakukan dengan metode review paper dari berbagai sumber yang akurat dan relevan seperti buku, jurnal dan artikel.
\end{abstract}

Kata Kunci: Daring, Strategi, Pembelajaran, Pandemi, Pendidikan Agama Islam

\begin{abstract}
Pandemic covid-19 is sweeping countries around the world, including Indonesia. Problems generated by the pandemic include education that causes all teaching learning to be done online to minimize the spread of the virus. In the learning of Islam, there are several challenges when teaching learners about materials whether they understand concepts or practices. Students, educatiors were required to be literate so that they could expect to follow and to learn from the devices as instructed by the ministry that requires all to do a PJJ Long distance Learning. Educators will be able to provide many learning choices that suit the needs of each learner as suggested by dictating that they should prepare learning in the form of the blended learning. The study aims to provide an overview of the implementation of islamic religious education with alternative strategies and innovation to facilitate the course of learning. The study used a qualitative approach done with the paper review method of various sources that are accurate and relevant, such as books, journals and articles.
\end{abstract}

Keywords: Online, strategies, Learning, Pandemic, Islamic education 


\section{PENDAHULUAN}

Pandemi COVID 19 menimbulkan banyak pengaruh dan perubahan yang signifikan di berbagai aspek kehidupan, sehingga semua dituntut untuk merespon hal tersebut secara guna mendapat solusi atas perubahan yang terjadi ${ }^{1}$. Setelah Corona menjadi wabah (pandemi) di Indonesia pada awal bulan Maret 2020 sampai sekarang belum ada penurunan jumlah kasus yang terpapar dan hingga saat ini pemerintah menghimbau masyrakat untuk melakukan sebagian besar kegiatan dari rumah, pemerintah membuat berbagai macam kebijakan untuk menghadapi dan mengatasi pandemi COVID-19 seperti kebijakan berdiam diri di rumah (stay at home), Pembatasan Sosial (social distancing), pembatasan fisik (Physical Distancing), penggunaan alat pelindung diri (masker), menjaga kebersihan diri dengan cuci tangan, belajar dan bekerja di rumah (work/study from home), menunda kegiatan yang mengumpulkan orang banyak, pembatasan sosial berskala besar (PSBB), dan pemberlakuan kebijakan new normal. Hal ini dilakukan oleh pemerintah guna meminimalisasi penyebaran dan penambahan cluster baru covid-19. Kebijakan tersebut merupakan implementasi dari surat edaran Mendikbud nomor 3 tahun 2020 tentang pencegahan COVID-19 pada satuan pendidikan, dan surat edaran nomor 4 tahun 2020 tentang pelaksanaan kebijakan pendidikan dalam masa darurat penyebaran COVID-19 (Coronavirus Deasae). Hingga saat ini masih diberlakukan untuk belajar dari rumah secara daring.

Saat terjadi wabah pandemik semua pihak merasakan perubahan yang sangat signifikan terutama di dunia pendidikan di Indonesia yang sepenuhnya belum siap untuk menghadapi tantangan pembelajaran dengan sistem daring. Berbagai masalah muncul saat awal diterapkannya pembelajaran daring ini dimulai dari kurangnya anggaran yang direalisasikan pemerintah, kurangnya penguasaan teknologi oleh siswa, guru, dan orang tua yang mendampingi dan akses internet yang belum merata dan terbatas keseluruh daerah-daerah. untuk mendukung terlaksanakannya pembelajaran daring ini. Berbagai upaya dilakukan semua pihak agar dapat dilaksanakan pembelajaran daring secara efektif dan merata di semua kalangan walaupun keterbatasan dana dan sistem pendukung pembelajaran daring yang belum merata dirasakan semua peserta didik di Indonesia. Berbagai alternatif strategi pembelajaran diberikan untuk memudahkan peserta didik dalam melaksankan pembelajaran secara daring.

Kualitas pembelajaran merupakan salah satu faktor yang sangat berperan dalam peningkatan mutu pendidikan oleh karenanya peningkatan kualitas pembelajaran merupakan faktor penting dalam meningkaatkan kualitas mutu pendidikan. Dengan segala sisi positif dan negatif yang dimiliki oleh pembelajaran daring, pelaksanaan pembelajaran tetap harus berpedoman pada tujuan dari pembelajaran itu sendiri. Selain itu seorang pendidik harus dapat meminimalisir kelemahan itu dengan menguasai berbagai strategi pembelajaran yang ada. Ada hal-hal yang harus dipertimbangkan dan dicermati oleh seorang pendidik jika ingin menerapkan strategi pembelajaran secara daring pada Pendidikan Agama Islam (PAI) pada proses pembelajaran daring dengan memilih yang efektif memudahkan muridnya, dikarenakan pembelajaran secara daring ini akan kurang dapat dikuasai oleh siswa karena waktu pelaksanaan pembelajaran ini dilakukan dirumah masing-masing siswa dengan segala keterbatasan yang berbeda.

Dalam pembelajaran Agama Islam dimasa pandemi terdapat beberapa kesulitan tantangan saat mengajarkan kepada peserta didik terkait materi baik itu secara pemahaman konsep maupun praktik, maka sebagai pendidik pentingnya melakukan berbagai strategi pembelajaran yang dapat dilaksanakan tanpa harus menyulitkan anak didiknya dengan memberikan metode pembelajaran secara tepat dengan memperhatikan gaya belajar agar peserta didik mendapat pemahaman pembelajaran secara cepat dan tepat. Pembelajaran daring ini semua pihak diharuskan dapat ikut berkontribusi dalam pelaksanaanya dengan orang tua ikut memantau dan mengawasi saat pembelajaran berlangsung setidaknya sesekali dalam

\footnotetext{
${ }^{1}$ Imas Novita Juaningsih et al., "Optimalisasi Kebijakan Pemerintah dalam penanganan Covid-19 terhadap Masyarakat Indonesia," SALAM: Jurnal Sosial dan Budaya Syar-i 7, no. 6 (April 17, 2020), accessed October 31, 2020, http://journal.uinjkt.ac.id/index.php/salam/article/view/15363
} 
seminggu agar meminimalisir kurangnya pemahaman peserta didik saat penyampaian materi oleh pendidik. Sebagai pendidik juga diharuskan meluangkan waktu sesekali dalam seminggu untuk memantau anak didiknya melalui video atau meluangkan waktu untuk mengunjungi anak didik yang tidak bisa akses pembelajaran melalui internet agar tidak tertinggal pelajaran.

\section{METODE PENELITIAN}

Penelitian ini merupakan analisis pustaka dengan tinjauan pustaka. Pengumpulan data dilakukan dengan melalui penelusuran literatur ilmiah secara sistematis pada artikel, jurnal, buku, serta sumber lainnya yang masih relevan yang membahas secara signifikan dan berkaitan dengan tema penelitian ini. Konteks yang menjadi penelitian ini adalah permasalahan yang terjadi pada saat pandemi Covid menyerang indonesia dan memberhentikan sekolah tatap muka yang menjadikan setiap orang mengalami permasalahan dalam belajar mengajar. Selanjutnya setelah dilakukan proses analisis, maka peneliti memberikan kesimpulan akhir sebagai penutup hasil penelitian ini.

\section{HASIL DAN PEMBAHASAN}

Salah satu indikator pendidikan yang berkualitas adalah adanya pembelajaran yang berkulitas, bukan hanya dari aspek sistem pengajaranya saja akan tetapi di nilai dan di lihat dari berbagai aspek salah satunya yaitu dari aspek pemanfaatan teknologi dan fasilitas pembelajaran yang ada, sehingga akan memancing reaksi peserta didik untuk lebih aktif dan berkembang sesuai dengan skill mereka masing-masing, maka dari di sini perlu sekali pengamatan dalam hal pemanfaaatan fasilatas teknologi yang ada di sekolah agar semua aspek berjalan sesuai dengan apa yang sudah menjadi tujuan pembelajaran yang ada. Semakin majunya sistem teknologi dan informasi di berbagai aspek kehidupan, menjadikan dunia pendidikan tak luput dari sasaran perkembangan teknologi. Dengan mengikuti perkembangan dan pemanfaatan dalam bidang teknologi informasi yang diterapkan pada pendidikan di Indonesia diharapkan pendidikan di Indonesia kelak memiliki daya saing global yang kuat dan akan menjadi lebih baik untuk kedepannya.

Pengertian TIK merupakan gabungan dari dua konsep yaitu information Technology dan Communication Technology, yang dirumuskan oleh (UNESCO,2003:7), yaitu information technology is the term used to describe the items of equeipment (hardware) and computer progam (software) that allow us to access, store, organize, manipulate, and present information by electronic means, communication technologhy is term used to describe telecommunication equipment, throught which information can be sought and accessed. Secara akademis teknologi insormasi dan komunikasi dapat di bedakan, akan teteapi pada prakteknya teknologi informasi dan komunikasi berbeda ibaraat dua sisi mata uang berbeda di mana kedua sisi tersebut sulit untuk di pisahkan, dalam konteks pembelajaran, menurut (siahan, 2010) pada zaman modern seperti sekarang ini penggunaan komputer memang di tekankan, akan tetapi TIK bukan hanya berpatok atau bertolak ukur pada alat ekektronik yang canggih melainkan juga mecangkup alat alat konvensional seperti bahan cetak, kaset audio, over head transparency $(\mathrm{OHT})$ overhead projektor, bingksai suara, televisi, radio. Seperti aap yang dikemukakan dengan pengambilan, pengumpulan, pengolahan, penyimpanan, penyeberan, dan penyajian informasi.

Teknologi pembelajaran adalah istilah inklusif untuk alat materi dan landasan teori untuk mendudkung pembelajaran dan pengajaran, pengertian dari sebuah teknologi pembelajaran tidak terbatas hanya pada taknologi tinggi, akan tetapi segala hal yang meningkatkan pembelajran di kelas maupun di luar kelas dalam rangka untuk pemanfaatan pembelajaran campuran, tatap muka ataupun online. Dengan begitu dalam hal pemanfaatan teknologi pembelajaran yang ada itu sangat amat lah banyak apalagi kita hidup di mana masa semakin berkembang dan berkemajuan, hal ini pun berpengaruh dalam dunia pendidikan dimana setiap lembaga pendidikan yang ada sudah semestinya memiliki media pembelajaran yang semakin canggih agar pembelajaran yang ada di sekolah tersebut memiliki keunggulan dalam meningkatkan semangat peserta didik dalam proses pembelajaran. Penggunaan media pembelajaran dalam proses belajar mengaajr juga bisa membangkitkan keinginan dan minat baru juga dapat dimanfaatkan dalam hal membangkitkan semangat belajar bagi peserta didik serta menambah kreativitas peserta didik dalam proses belajar mengajar, serta menambah 
motivasi dan rangsangan dalam kegiatan belajar bagi peserta didik agar materi yang di sampaikan oleh guru pun bisa di serap dengan mudah dan efesien oleh peserta didik, bahkan dalam pemanfaatan media pembelajaran ini pun sangat lah berpengaruh baik terhadap psikologis peserta didik.

Pemanfaataan dan penggunaaan media pembelajaran dalam tahap orientasi pembelaran pun sangat lah membantu tenaga pengajar agar terciptanya kefektifan dalam proses belajar mengajar, peserta didik pun merasa tidak bosen akan materi yang di sampaikan oleh seorang karena di topang dengan media pembelajaran yang di manfaatkan oleh pendidik. Tidak sampai di situ saja pemanfatan media pembelajaran ini pun sangat membantu peserta didik dalam upaya memahami dan menerima pesan, motivasi, bahkan isi terkait pembelajaran yang sedang berlangsung di waktu proses belajar mengajar berlangsung, bahkan guru pun merasa sangat terbantu akan adanya media pembelajaarn yang lambat laun semakin canggih, dan memudahkan tenaga pengajar dalam penyampaikan informasi tentang keilmuan serta mempermudah tenaga pengajar dalam menyajikan data dengan gaya yang menarik dan di percaya akan sumber yang di peroleh oleh tenaga pengajar, serta memudahkan dalam hal penafsiran data, dan memdatkan informasi-informasi yang di sampaikan oleh seorang guru kepada peserta didik.

Menurut Syaridudin, sebuah inovasi pembelajaran dikarakan berhasil dengan karakteristik sebagai berikut:

1. Terdapat keuntungan relatif baik bagi pembuat inovasi maupun sasaran inovasi

2. Memiliki sifat kompatibel yaitu adanya keselarasan antara nilai, pengalaman, kebutuhan sasaran kompleksitas yang artinya mencangkup keseluruhan

3. Bersifat triabilitas yaitu inovasi yang ada apakah dapat dicoba atau ridak dalam kehidupan penerima

4. Bersifat observiabilitas, yaitu inivasi dapat diamati hasilnya ${ }^{2}$

\section{B. PEMBELAJARAN DARING}

Teknologi berperan penting sebagai penunjang pembelajaran terutama pada saat pandemi ini. Berbagai jenis produk teknologi seperti e-learning, google classroom, google meet, zoom, dan youtube telah memberikan peran yang besar. Kemendikbud memberikan kebebasan untuk setiap sekolah untuk memilih platform belajar daring. Untuk mendorong adanya proses berbagi pengetahuan, kemendikbud menyediakan platform belajar daring gratis bernama "rumah belajar"dan platform untuk guru bernama "progam guru berbagi". Rumah belajar menyediakan bahan mengajar dan fitur komunikasi, sedangkan progam guru berbagi berbagi RPP dengan guru di seluruh indonesia. Untuk darah dengan koneksi internet tidak baik pemerintah bekerjasama dengan TVRI untuk menyampaikan materi belajar yang ada di dalam progam belajar di rumah. selain itu pemerintah juga memberihan subsidi kuota gratis untuk jenjang SD, SMP, SMA, dan perguruan tinggi untuk menunjang pembelajaran daring. Dengan adanya berbagai kendala yang dihadapi tidak semua peserta didk di tempat tinggalnya tersedia jaringan internet yang memadai tetapi untuk peserta didik yang tempat tinggalnya memadai tenaga pengajar bisa melaksanaknnya dengan menggunakan aplikasi yang ada.

Adapun beberapa aplikasi yang sering digunakan untuk mendia pembelajaran daring antara lain dari aplikasi yang mudah hingga aplikasi yang masih jarang digunakan.

1. E-learning merupakan media pembelajaran yang bersistem website yang memanfaatkan teknologi dalam pembelajaran yang dapat di akses dimana saja. Elearning disediakan oleh kampus untuk media pembelajaran yang dapat digunakan

\footnotetext{
2 Masruroh Lubis1, “Pembelajaran Pendidikan Agama Islam Berbasis E-Learning”, Fitrah: Journal of Islamic Education, Vol. 1 No. 1Juli 2020
} 
hingga saat ini. Terdapat berbagai fitur yang masih belum bisa dipahami beberapa tenaga pengajar dan

2. Google Classroom sebagai media belajar online yang memudahkan dosen dan mahasiswa. Google classroom memiliki berbagai fitur yang lengkap seperti untuk mahasiswa dikarenakan kurang pahammya teknologi yang terapkan di E-learning. Adapun kendala yang ada di E-learning ini seperti server down, jaringan internet dan perlu pemahaman untuk menggunakan E-learning.mengirim tugas, menjawab soal, presensi, dan berbagai fitur yang memudahkan tenaga pengajar dan mahasiswa. Google classroom menggabungkan google docs, drive, slides, gmail dan kalender. Google Classroom ini tidak memerlukan banyak kuota atau jaringan internet yang memadai, biasannya digunakan untuk model perkuliahan asinkron.

3. Zoom Meeting merupakan sebuah media pembelajaran menggunakan video. Aplikasi ini tidak hanya digunakan untuk pembelajaran saja akan tetapi dapat digunkan siapapun dan dimanapun. Dalam aplikasi Zoom Metting ini kita dapat bekomunikasi lewat video. Penggunkan aplikasi dinilai kurang efektif untuk media pembelajaran dikarenakan ada beberapa mahasiswa yang terkendala jaringan internet dan kuota.

4. Google Meet media pembelajaran online yang biasa digunakan untuk pertemuan melalui video yang hampir mirip dengan aplikasi zoom. Google meet dinilai lebih efisien waktu saat digunakan tidak sulit. Pendidik dan mahasiswa lebih menyukai aplikasi ini saat pembelajaran berlangsung, seperti yang lain kendalannya terletak di jaringan internet.

5. Power Point aplikasi ini sering digunakan untuk presentasi saat daring maupun luring sangat efisiensi waktu dalam mempresentasikan materi mudah digunakan semua baik tenaga pengajar maupun mahasiswa. Sangat mudah digunakan dan sangat membantu dalam tugas perkuliahan tidak memerlukan jaringan internet.

6. Aplikasi Youtube juga dipilih oleh pengajar dengan memberi tugas mereview video atau membuat tugas membuat video. Kendalannya yang sering terjadi jaringan internet dan kuota. Aplikasi ini tidak terlalu membebani siswa cukup memudahkan saat digunakan.

7. Aplikasi WhatsApp sering digunakan saat sebelum pandemic aplikasi ini memudahkan tenaga pengajar maupun mahasiswa dalam melaksanakan perkuliahan. Terdapat beberapa fitur yang dapat digunakan saat memulai perkuliahan daring. Kelemahan aplikasi ini hanya bisa melakukan video terbatas untuk 8 orang saja maka kurang efisien jika dalam satu kelas ada 30an mahasiswa. Tetapi aplikasi ini sering digunakan dengan bertukar chat atau diskusi ringan dan dapat berlanjut sampai lain waktu.

Walaupun terdapat kendala saat pembelajaran daring dengan menggunakan aplikasi, para pendidik dan mahasiswa dapat menggunakan opsi-opsi lain yang kiranya dapat memudahkan semua misal aplikasi WhatsApp yang dapat mengirimkan berbagai jenis file, video pembelajaran, rekaman suara, video Call, dan lain sebagainnya, dengan begitu dapat meminimalisir terjadinya masalah masalah yang dapat mengganggu proses pembelajaran sehingga perkuliahan dapat berlangsung seperti biasa. Pembelajaran daring tidak sepenuhnya menjadi solusi bagi pendidikan karena pembelajaran daring belum bisa menggantikan pembelajaran tatap muka. Berikut adalah kesulitan dalam pembelajaran daring:

1. Susah sinyal/jaringan.

Sinyal merupakan kendala utama dalam pembelajaran daring, terutama dalam kondisi pandemi ini. Sinyal yang bagus sangat memudahkan pembelajaran daring, begitu juga sebaliknya sinyal yang kurang bagus sangat menyulitkan mahasiswa untuk melakukan pembelajaran daring. Selain itu banyak juga mahasiswa yang mengatas namakan sinyal untuk malas mengikuti perkuliahan dan untuk orang yang tinggal di pedesaan dan pelosok sangat susah untuk mengikuti perkuliahan karena sinyal yang didapatkan kurang bagus.

2. Kuota/paket internet.

Paket internet merupakan hal yang sangat dibutuhkan, dengan paket internet pembelajaran daring bisa dilakukan. Apa jadinya bila paket internet susah untuk dibeli, tentunya akan mempersulit mahasiswa untuk mengikuti perkuliahan. Era pandemi ini menyusahkan orang untuk melakukan pekerjaan dan menurunkan ekonomi seseorang. Walaupun ada solusi dari 
pemerintah yang merupakan pemberian paket internet secara gratis, tapi masih susah digunakan karena ada pembatasan dalam penggunaannya.

3. KBM tidak efektif.

Kegiatan pembelajaran secara daring tentunya tidak efektif untuk dilaksanakan, karena ada beberapa faktor seperti mahasiswa yang malas menatap layar telepon atau laptop karena lamanya perkuliahan, Berkurangnya jam perkuliahan karena banyak mahasiswa yang diam ketika perkuliahan dan membuat dosen untuk cepat mengakhiri perkuliahan. Ketidak efektifan tersebut ditambahi dengan banyaknya tugas yang menumpuk dengan deadline pengumpulang yang relatif singkat. Selain itu bantak terjadinya gangguan saat sedang belajar. Gangguan menjadi slah satu knci mengapa fokus sulit dibangun. Salah satu faktor yang membangun fokus tergantung pada dorongan eksternal yang wecara garis besar ada dua prinsip, yaitu prinsip kesenangnan dan aturan.

\section{STRATEGI PEMBELAJARAN DARING PAI}

Dalam dunia pendidikan, strategi diartikan sebagai rencana, metode, atau rangkaian kegiatan yang dirancang untuk mencapi tujuan pendidikan tertentu. Jadi, strategi pembelajaran dapat disebut sebagai rancangan yang merancang suatu kegiatan dalam pembelajaran untuk mencapai suatu tujuan pendidikan tertentu. Istilah strategi, banyak istilah lainnya, banyak dipakai dalam konteks dengan makna yang tidak selalu sama. Di dalam konteks belajar mengajar, strategi berarti pola umum aktivitas guru dan peserta didik di dalam perwujudan kegiatan belajar mengajar. Sifat umum pola tersebut berarti bahwa macam dan urutan perbuatan yang dimaksud tampak dipergunakan guru dan peserta didik di dalam bermacammacam peristiwa belajar. Berdasarkan istilah diatas, konsep strategi menunjukkan bahwa pola belajar mengajar antara guru dan murid tidak menentu. Di balik itu ada pemahaman rasional yang membedakan strategi yang satu dari strategi yang lain secara mendasar. Istilah lain dari maksud diatas adalah rnodel-model pembelajaran; sedangkan rangkaian kegiatan guru dan murid dalam suatu peristiwa belajar rnengajar disebut metode pembelajaran. Para ahli pendidikan telah banyak memberikan definisi mengenai pengertian strategi pembelajaran. Berikut ini akan diuraikan beberapa definisi tersebut, antara lain.

1. Kemp

Strategi pembelajraran adalah suatu kegiatan pembelajaran yang harus dikerjakan guru dan peserta didik agar tujuan pembelajaran dapat dicapai secara efektif dan efisien

2. Kozma

Strategi pembelejaran adalah sebagai kegiatan yang dipilih yaitu yang dapat memberikan fasilitas atau bantuan kepada peserta didik menuju tercapainya tujuan pembelajaran tertentu

\section{Gerlach dan Ely}

Strategi pembelajaran merupakan cara..cara yang dipilih untuk menyampaikan materi pembelajaran dalam lingkungan pembelajaran tertentu.

Strategi pembelajaran adalah rangkaian kegiatan dan termasuk penggunaan metode dan memanfaatkan sumber daya yang ada dalam pembelajaran. Artinya penyusunan suatu strategi baru sampai pada proses penyusunan dan belum belum sampai pada tindakan. Kedua, strategi disusun untuk mencapai tujuan tertentu. Artinya, arah dari semuan strategi yang ada adalah untuk mencapai suatu tujuan. Dengan demikian, seluruh strategi yang ada mulai dari penyusunan langkah-langkah pembelajaran, pemanfaatan fasilitas dan sumber belajar semuanya diarahkan untuk mencapai suatu tujuan. Oleh karena itu, sebelum membuat strategi pembelajaran, perlu dipikirkan dulu tujuan yang jelas agar dapat diukur keberhasilannya, sebab tujuan adalah hal utama untuk melaksanakan suatu strategi. Strategi pembelajaran merupakan kegiatan pembelajaran dengan menggunakan cara-cara dan fasilitas yang efektif dilakukan oleh pendidik untuk mengajarkan kepada peserta didik berupa materi agar peserta didik tersebut memiliki pengalaman belajar dari pendidik. Dalam hal ini penjelasan tentang strategi pembelajaran memiliki arti yang sangat luas dimulai dari pelaksanaan prosedur dan perancagan tahapan kegiatan melainkan juga termasuk materi dan paket pembelajaran yang 
disampaikan oleh pendidik kepada peserta didiknya. Dalam penerapannya di pembelajaran daring PAI kita dapat menerapkannya pada pelaksanaan pembelajaran saat ini yang dinilai dapat efektif untuk melakukan pembelajaran daring dengan strategi pembelajaran tersebut.

Strategi pembelajaran berbeda dengan desain instruksional, strategi pembelajaran memiliki berbagai pola dalam artian proses belajar mengajar antara satu dengan yang lain memiliki perbedaan dan tidak selalu sama, sedangkan desain instruksional lebih mengarah pada cara-cara merencanakan sesuatu sistem dilingkungan belajar tertentu. Kalau di ibaratkan dengan tempat kuliah, strategi pembelajaran adalah ibarat mencari berbagai kemungkinan tempat kuliah yang akan kita tuju seperti kuliah di universitas negeri atau swasta. Sedangkan desain instruksional adalah mencari cara bagaimana agar bisa diterima diuniversitas yang diinginkan, mulai dari cari informasi kapan mulai penerimaan mahasiswa baru, apa saja persyaratan yang dibutuhkan hingga bisa terpilih jadi mahasiswa ditempat yang diinginkan.

Dari uraian diatas, dijelaskan bahwa sebagai seorang guru yang profesional memerlukan wawasan yang mantap tentang kemungkinan-kemungkinan yang akan terjadi dalam pembelajaran. strategi pembelajaran harus sesuai dengan tujuan-tujuan belajar, baik dalam arti efek instruksional maupun efek pengiring, yang ingin dicapai berdasarkan rumusan tujuan (kompetensi) yang utuh, disamping itu keahlian dalam mendesain sistem lingkungan belajar mengajar sangat diperlukan untuk mengimplementasikan secara efektif apa yang telah direncanakan di dalam desain instruksional. Ceramah, diskusi, LCD, video tape, penggunan narasumber dan lainnya merupakan metode, teknik dan alat yangmenjadi bagian dari perangkat alat dan cara didalam pelaksanaan strategi pembelajaran seringkali harus dipergunakan lebih dari satu strategi karena tujuan yang akan dicapai juga saling berkaitan denganyang lain dalam rangka usaha pencapaian tujuan lebih umum. Dibutuhkan pemahaman terhadap pengertian lain yang mirip dengan strategi pembelajaran yang selalu digunakan seperti model pendekatan, strategi, metode dan teknik. Dalam referensi kependidikan sering disandingkan antara pengertian tersebut dengan maksud yang serupa.

Kualitas pembelajaran merupakan salah satu faktor yang sangat berperan dalam peningkatan mutu pendidikan. peningkatan kualitas pembelajaran merupakan faktor penting dalam meningkaatkan kualitas mutu pendidikan. Berbagai macam bentuk strategi pembelajaran yang bisa diterapkan dalam pembelajaran termasuk blended learning yang diusulkan oleh kemendikbud. Bebrapa penelitian telah menemukan bahwa bleanded learning dapat meningkatkan hasil belajar sama atau lebih tinggi dari mahasiswa yang belajar secara konvensional atau sepenuhnya daring, meskipun tingkat keberhasilan bervariasi antara disiplin ilmu. Metode mengajar ini lebih menekankan kepada siswa agar dapat fokus dalam pelaksanaan pembelajaran daring, guru dapat mengkombinasikan metode mengajar yang efektif dalam pelaksanaan daring saat ini dalam pembelajran Pendidikan Agama Islam. Sebagai seorang pendidik hendaknya kita dapat berinovasi menciptakan berbagai metode pembelajaran pada pelajaran PAI yang dapat diterapkan saat pandemi. Menurut Febrianto Amri Ristadi, S.T., M.Eng.Sc. (Dosen JPTM FT UNY), mahasiswa diharapkan tidak terpaku pada satu strategi saja tetapi juga bisa menggunakan strategi yang lain, sehingga dapat terakomodasi dan tidak tertinggal belajarnya. Hal tersebut juga disampaikan dalam materinya tentang blended learning agar semua gaya belajar terakomodasi ${ }^{3}$

Dengan segala sisi positif dan negatif yang dimiliki oleh pembelajaran daring, pelaksanaan pembelajaran tetap harus berpedoman pada tujuan dari pembelajaran itu sendiri. Pembelajaran daring memiliki sisi positif dan negatif. Berikut beberapa metode yang dapat digunakan dalam pembelajaran daring selama pandemic covid-19:

\section{Metode ceramah}

Metode ceramah dapat diartikan sebagai cara menyajikan pelajaran melalui penuturan secara lisan atau penjelasan langsung kepada sekelompok siswa (Sanjaya, 2006). Untuk membuat lebih menarik, pengajar dapat membuat penjelasan materi dalam bentuk video pembelajaran. Keunggulan video pembelajaran yang dibuat oleh pengajar akan memudahkan pembelajar untuk memahami materi pelajaran karena bisa diulang mempelajari apabila ada materi yang belum dimengerti.

\footnotetext{
${ }^{3}$ https://www.uny.ac.id/berita/strategi-pembelajaran-daring-selama-pandemi
} 


\section{Metode diskusi}

Metode diskusi dapat diartikan sebagai penyajian pelajaran dimana siswa dihadapkan pada suatu masalah yang bisa berupa pertanyaan dan pertanyaan yang bersifat problematis untuk dibhas dan dipecahkan bersama. (Aswan\&Bahri Syamsul,2006). Metode ini sangat bagus digunakan untuk membuat pembelajaran menjadi kritis serta mendorong mereka untuk mengekspresikan ide dan pikirannya. Diskusi dapat dilaksanakan melalui video conference secara langsung dengan menggunakan zoom, goggle meet, webex dan aplikasi video conference lainnya. Diskusi juga dapat dilakukan dengan saling berbalas komentar pada google classroom, komentar yang diberikan dalam bentuk tulisan.

\section{Metode Demonstrasi}

Metode demonstrasi disajikan dengan cara memperagakan barang, kejadian, aturan dan urutan melakukan kegiatan, baik secara langsung maupun melalui penggunaan media pengajaran yang relevan dengan pokok bahasan atau materi yang sedang disajikan (Syah,2000). Metode ini digunakan untuk memperagakan kejadian atau urutan kejadian. Demonstrasi dapat dilakukan langsung melalui aplikasi video conference ataupun dengan bantuan media video. Dalam hal ini pengajar dapat membuat video tentang mereka saat menjelaskan sesuatu.

4. Metode resitasi

Metode ini mengharuskan pembelajar untuk membuat resume dengan kalimat sendiri. Materi dapat berupa bacaan atau video pembelajaran. Setelah membaca atau menonton, pembelajar harus membuat resume sendiri. Hal ini dapat membuat pembelajar bertanggung jawab dan percaya diri terhadap pekerjaan mereka.

5. Metode pemecahan masalah

Metode ini mengajarkan penyelesaian masalah dengan memberikan penekanan pada terselesaikannya suatu masalah secara menalar (Gulo, 2002). Pembelajar dapat diberikan soal lalu diminta untuk mencari penyelesaiannya. Metode ini melatih pembelajar untuk berpikir kritis, mandiri dan kreatif.

6. Metode discovery

Metode ini meminta pembelajar untuk mencari sendiri materi yang akan dipelajari, metode ini melatih keterlibatan pembelajar secara aktif dalam proses pembelajaran.

7. Metode inquiry

Metode inquiry adalah rangkaian kegiatan belajr yang melibatkan secara maksimal seluruh kemempuan siswa untuk mencari dan menyelediki secara sistematis, kritis, analitis, dan logis sehingga dapat merumuskan sendiri penemuannya (Gulo,2002). Pengajar menjelaskan materi lalu pembelajar diberikan beberapa pertanyaan terkait materi yang dibahas. Pengajar dapat membantu pembelajar menjawab pertanyaan yang sulit dipahami pembelajar. Di akhir pembelajaran, pembelajar membuat rangkuman materi. berikut:

Adapun klasifikasi strategi pembelajaran yang dijelaskan dalam buku hamruni sebagai

\section{Strategi pembelajaran langsung}

Penerapan srategi pembelajaran ini dengan guru yang berperan aktif dalam melaksanakan pembelajaran ini dengan guru mengarahkan muridnya saat proses pembelajaran dengan lebih aktif memberikan materi pembelajran. Strategi pembelajaran langsung ini keuntungan menerapkannya pada proses mengajar yaitu mudah direncanakan dan digunakan adapun kelemahannya yaitu mengembangkan pengetahuan cara berpikir kritis peserta didik saat pembelajaran kelompok untuk hasil yang maksimal dalam meggunakan strategi pembelajran ini pendidik harus mengkombinasikan dengan strategi pembelajran yang lainnya

\section{Strategi pembelajaran tak langsung}

Strategi ini juga disebut dengan pengambilan keputusan oleh pendidik saat menerapkannya pada pembelajaran. Berbeda dengan strategi pembelajaran langsung dalam strategi pembelajaran tak langsung ini lebih berpusat kepada peserta didik. Dalam hal ini seorang guru tugasnya bukan menjelaskan materi pembelajaran akan tetapi seorang guru lebih berperan 
sebagai fasilitator bagi muridnya dalam pelaksanaan pembelajaran. Dalam strategi ini peran peserta didik sangat dikedepankan, peserta didik lebih berperan aktif dalam proses belajar mengajar. Keuntungan menggunakan strategi ini yaitu seorang guru dapat mendorong peserta didik dalam ketertarikan dan keingin tahuan pada pembelajaran yang dijelaskan oleh pendidik. Adapun kekurangan dalam strategi pembelajaran tak langsung pendidik lebih memerlukan banyak waktu dalam pengajar dan pencapaian peserta didik sulit di prediksi. Peserta didik yang memiliki tingkat fokus dalam pembelajran yang kurang tidak disarankan bagi pendidik untuk menerapkan strategi ini dalam proses mengajar.

\section{Strategi pembelajaran interaktif}

Strategi ini lebih menerapkan model diskusi dan sharing pembelajaran antar pendidik dan peserta didik saat berlangsungnya proses pembelajaran. Dalam strategi ini peserta didik dapat berperan aktif dengan bereaksi terhadap apa yang guru ajarkan, gagasan yang ingin diungkapkan atau pengetahuan tentang guru dan murid lainnya untuk mengembangkan kemampuannya berfikir saat proses diskusi materi dengan lainnya.

4. Strategi pembelajran empikirik (experiential)

Strategi ini lebih berorientasi pada kegiatan induktif yang berpusat pada peserta didik dengan pembelajaran yang berbasis bebas memudahkan dalam proses penyampaian materi oleh pendidik. Strategi ini menerapakan pengalaman dengan formulasi perencanaan menuju penerapan yang berkonteks pada faktor kritis dalam pembelajran yang efektif. Kelebihan dari strategi ini peserta didik lebih banyak berpartisipasi dalam pembelajaran lalu mengingkatkan kemampuan peserta didik dalam berpikir kritis dalam menghadapi kesulitan dalam memsahami materi yang disampaikan oleh pendidik. Kekurangannya pendidik lebih menekankan proses bukan hasil dalam mengajar hal ini juga terlalu memberatkan peserta didik dalam aspek keamanan, biaya, dan waktu dalam proses pembelajaran.

\section{Strategi pembelajaran mandiri}

Strategi ini dapat diguanakan oleh pendidik dikarenkan strategi ini bertujuan untuk membangun semangat peserta didik dengan berinisiatif melakukan pembelajaran secara individu agar memiliki sifat kemandirian dan peningkatan diri yang singnifikan. Pembelajaran ini berfokus belajar mandiri peserta didik yang dibantu oleh guru dalam pelaksanaanya. Kelebihan dari pembelajran ini yaitu dapat membentuk sifat kemadirian pada peserta didik dan juga rasa bertanggung jawab terhadap tugasnya sebagai murid saat pembelaran berlangsung. Untuk kekurangannya strategi ini kurang efektif apabila ditetapkan pada anak yang belum dewasa cara berpikirnya dikarenkan belum bisa menerima materi dengan belajar secara mandiri. Dalam setiap srategi pembelajaran akan ada kelemahan dan kekuragannya maka dari itu sebagai seorang pendidik harus dapat meminimalisir kelemahan itu dengan menguasai berbagai strategi pembelajaran yang ada.

Pelaksanaan pembelajaran tetap harus berpedoaman pada tujuan dari pembelajaran itu sendiri. Berikut beberapa strategi pembelajaran daring yang dapat digunakan dalam pembelajaran daring selama pandemi Covid-19.

\section{Guru mengatur waktu dengan efektif}

Bagi sebagian murid yang belum terbiasa belajar sendiri dirumahnya mungkin pembelajaran jaring ini menjadi sangat membosankan bagi sebagian murid dari masalah ini guru harus mengoptimalkan waktu belajar seefektif mungkin agar perhatian siswa terhadap materi pelajaran yang diajarkan guru dapat diserap secara optimal. Pembelajaran daring dalam pembelajaran Pendidikan Agama Islam ini terkesan cukup menyulitkan dari pihak pendidik dan peserta didik dalam pelaksanaannya. Semua ini dapat diatasi apabila semua pihak dapat fokus dalam pelaksanaannya.

\section{Mempersiapkan media Teknologi yang ingin digunakan saat menyampaiakn materi}


Saat pandemi semua media pembelajaran dialihkan ke media daring sebagian besar harus menggunakan teknologi seperti handphone, laptop komputer, tablet dan lain-lain yang sekirannya dibutuhkan untuk memulai pembelajaran jaring. Saat pembelajaran daring pada pendidikan agama islam dapat menggunkan media WhatsApp, Zoom, Google Meet, dan layanan berbasisi internet. Pendidik dapat memilih ingin menggunakan aplikasi atau media apa yang digunakan untuk menyampaikan materi pada muridnya dapat memilih materi yang sekirannya memudahkan semua murid dapat menggunkan aplikasi tersebut dikarenakan tidak semua daerah memiliki jaringan internet yang stabil dan para siswa memiliki biaya untuk membeli kuota untuk pembelajaran. Akan tetapi saat ini pemerintah sudah memfasislitasi perbulannya memberikan kuota gratis untuk mengikuti pembelajaran daring.

\section{Mengarahkan dan memotivasi murid agar belajar dengan serius dan disiplin}

Saat pembelajaran daring sebagai seorang pendidik kita tidak dapat mengawasi murid seperti saat disekolah mereka berada di rumah masing-masing yang jaraknya berbeda-beda. Alangkah lebih baiknya sebagai pendidik kita memantau murid dan memberikan pengertian lebih sebelum dimulainnya pembelajaran agar materi yang disampaikan pendidik dapat dimengerti dan diserap oleh murid dengan baik. Sebagai pendidik kita bisa sesekali melakukan pemantauan dengan video melalui google meet atau zoom memberikan motivasi belajar untuk murid-murid memberikan pengerian tentang disiplin dalam belajar saat kondisi bagaimanapun.

\section{Selalu menjaga komunikasi pada murid}

Bagi yang belum terbiasa menggunakan media daring sebagai pembelajaran dapat diberikan arahan untuk terbiasa menyesuaikan diri dengan kondisi saat pandemi. Pendidik memiliki tanggung jawab yang besar untuk mencerdaskan murid agar sukses kelak dikemudian hari. Sebagai pendidik kita perlu mengadakan grup secara daring dengan aplikasi WhatsApp untuk memantau murid dan menjalin komunikasi yang baik dengan murid dengan sesekali menanyakan apa ada kesulitan saat mengerjakan tugas yang diberikan oleh guru atau ada kendala lainnya misalnya terkait kuota atau yang lainnya. Sebagai pendidik sebisa mungkin memanfaatkan dengan baik media-media yang digunkan saat pembelajaran daring. Dalam pembelajaran pendidikan agama islam menggunakan media daring ini juga ada altenatif jitu sebagai pengganti pertemua pemebelajaran tatap muka dikelas dapat digantikan dengan media daring.

Ada hal-hal yang harus dipertimbangkan dan dicermati oleh seorang pendidik jika ingin menerapkan strategi pembelajaran secara daring pada Pendidikan Agama Islam (PAI) pada proses pembelajaran daring dengan memilih yang efektif memudahkan muridnya, dikarenakan pembelajaran ini secara daring akan kurang dapat dikuasai oleh siswa karena waktu pelaksanaan pembelajaran ini dilakukan dirumah masing-masing siswa. Pada pembelajaran daring Pendidikan Agama Islam siswa sangat membutuhkan penjelasan materi yang detail oleh guru agar dapat diimplementasikan dan melekat pada kehidupan sehari-hari murid. Sebagai seorang guru pendidikan Agama islam harus membuat inovasi-inovasi strategi pembelajaran yang dapat diterapkan dengan baik saat daring.

Cara mengajar pendidikan Agama Islam saat daring dapat menggunakan metode tidak memberatkan siswanya guru dapat mengubah metode ceramah tanpa video dengan membuat rekaman penjelasan pembelajaran lalu dapat dikirim melalui aplikasi WhatsApp yang tidak membutuhkan banyak kuota untuk membukannya. Atau dengan media powerpoint untuk menjelaskan materi dengan jelas ini juga media yang dapat meringankan siswa untuk mendapat materi dari gurunya dengan cara yang mudah. Ada cara lain yang dapat digunakan pendidik dalam pembelajaran daring yang cukup mudah dengan google form atau google classroom media ini diguanakan untuk memantau keaktifan siswa dalam proses pembelajaran daring saat pandemi Covid-19. Media ini mungkin hanya sebagian siswa yang dapat menggunakannya dikarenakan diperlukan jaringan dan kuota yang cukup untuk dapat mengikuti pembelajaran daring. Bagaimanapun caranya semua siswa juga dapat berusaha dan beradaptasi dengan strategi pembelajaran daring yang diterapkan oleh pendidik. Dengan segala sisi positif dan negatif yang dimiliki pembelajaran daring. 


\section{KESIMPULAN}

Dunia sedang dilanda pandemi covid-19 yang mengubah sebagian besar kegiatan dari semua sektor termasuk pendidikan. Pendidikan harus dapat memastikan kegiatan belajar mengajar dapat berjalan dengan lancar oleh karenanya pendidikan mengubah proses pembelajaran dari yang semula bertatap muka menjadi dalam jaringan sesuai dengan edaran kemendikbud Nomor 4 Tahun 2020 tentang Pelaksanaan Kebijakan Pendidikan dalam Masa Darurat Penyebaran Corona Virus Disease (Covid-19). Teknologi pembelajaran adalah istilah inklusif untuk alat materi dan landasan teori untuk mendudkung pembelajaran dan pengajaran, pengertian dari sebuah teknologi pembelajaran tidak terbatas hanya pada taknologi tinggi, akan tetapi segala hal yang meningkatkan pembelajran di kelas maupun di luar kelas dalam rangka untuk pemanfaatan pembelajaran campuran, tatap muka ataupun online. Tidak sampai di situ saja pemanfaatan media pembelajaran ini pun sangat membantu peserta didik dalam upaya memahami dan menerima pesan, motivasi, bahkan isi terkait pembelajaran yang sedang berlangsung di waktu proses belajar mengajar berlangsung. Pembelajaran online dilakukan dengan berbagai media pembelajaran seperti google classroom, e-learning, zoom, youtube, google meet dan media pembelajaran lainnya. Dengan adanya platform pembelajaran memudahkan pendidik untuk memberikan materi kepada peserta didik sehingga pembelajaran dapat dilakukan dengan baik. Walaupun banyak manfaat pembelajaran online ini tidak sepenuhnya sempurna dengan dilihat dari banyaknya kendala-kendala seperti kekuatan sinyal yang buruk, perangkat yang digunakan tidak mensupport pembelajaran, kuota dan paket internet serta ketidakefektifan pembelajaran.

\section{DAFTAR PUSTAKA}

Moore, Peter, 2003. Komunikasi dalam Pembelajaran, Environment of e-learning, UNESCO, Jakarta: Pustekkomdiknas

Hamruni, 2009. Strategi dan Model-model Pembelajaran Aktif-Menyenangkan. Yogyakarta: Fakultas Tarbiyah UIN Sunan Kalijaga Yogyakarta,

Ketut Sudarsana , 2020. COVID-19: Perspektif Pendidikan. Bali:Yayasan Kita Menulis, hlm. 49

Imas Novita, 2020. Optimalisasi Kebijakan Pemerintah dalam penanganan Covid-19 terhadap Masyarakat Indonesia. SALAM: Jurnal Sosial dan Budaya Syar-i 7, no. 6 (April 17, 2020), accessed October 31, 2020 (Juaningsih et al., n.d.)

Masruroh Lubis1, 2020. Pembelajaran Pendidikan Agama Islam Berbasis E-Learning, Fitrah: Journal of Islamic Education, Vol. 1 No. 1 Juli 2020(Libis Masruroh, 2020)

Ni Komang, 2020. Pemanfaatan Teknologi Informasi dalam Pembelajaran Tingkat Sekolah Dasar pada Masa Pandemi Covid-19, Jurnal Lampuhyang Lembaga Penjaminan Mutu Stkip Agama Hindu Amlapura, LAMPUHYANG Vol. 11 No.2 Juli(Lampuhyang et al., 2020)

Yudhi A, 2018. Desain Media Pembelajaran Berbasis Daring Memanfaatkan Portal Schoology pada Pembelajaran Apresiasi Sastra. Jurnal Basatra. Vol.7 No.1(Yuhdi A, 2018)

Narwan, 2020. 4 strategi pembelajaran daring di masa pandemi covid-19. Website: https://siedoo.com/berita-30442-berikut-4-strategi-pembelajaran-daring-di-masa-pandemi-covid19/?amp

UNY. 2020. Strategi Pembelajaran Daring Selama Pandemi. Website: https://www.uny.ac.id/berita/strategi-pembelajaran-daring-selama-pandemi 